\title{
The composition of the faecal microbial flora of milking cows on feeds containing urea as the sole or partial source of nitrogen
}

\author{
T. Ettala, A. Seuranen and M. Kreula \\ Biochemical Research Institute, Kalevankatu 56 B, SF-00180 Helsinki 18, \\ Finland
}

\begin{abstract}
Using a variety of culture media, counts of live bacteria in the faeces of milking cows on purified, protein-free feed in which urea was the only source of nitrogen (0-cows) and on urea-rich, low-protein feed (ULP-cows) were made. Samples were taken from 3 0-cows and 3 ULP-cows weekly. Counts of lactobacilli, micrococci, propionic acid bacteria and lactate-utilising butyric acid bacteria were made during a period of 41 weeks, and counts of anaerobic and aerobic bacteria, enterococci and coliform bacteria for 26 weeks. Counts are given as $\log _{10}$ number/g fresh faeces.

In the 0 cows anaerobic bacteria counts were $5-9$, ULP cows $6-9$; aerobic bacteria were $5-7$ and $5-8$ respectively.

Propionic acid bacterias counts were $4-7$ with both 0 - and ULP cows, lactobacilli $3-8$ in 0 cows and $4-8$ in ULP cows, and micrococci $2-7$ in both groups. Enterococci were $2-6$ in 0 cows and $3-7$ in ULP cows, and coliforms $3-6$ and $2-6$ respectively. Laciate utilising butyric acid bacteria were $0-4600 / \mathrm{g}$ fresh faeces, being fewer in 0 cows than in ULP cows. There was large variation in the counts of all bacteria from one week to the next. In a single cow almost all the bacterial counts could be low at the same time and the following week they could all be high. In different animals the timing of these variations was not the same. The counts of bacteria growing under anaerobic conditions were the main exception to the above variations.

The ratio between gram-negative and gram-positive bacteria in faeces was measured and it was found that with both types of test feed the gram-negative were more numerous. In addition the occurrence of bacterial spores was studied; their counts, as a proportion of the total number of bacteria reacting to stain, averaged 6.5 and $26.7 \%$ respectively in 0 - and ULP-cows.
\end{abstract}

\section{Introduction}

In young animals the faecal microbial flora is uniform, that is speciesindependent, but in the adult animal each species has its own characteristic bacteria (Sмrтh 1961). The uniformity, according to Smith, is due to the 
similarity of the diet (milk) and to the early stage of development of the digestive tract. However Medrek and Barnes (1962) found that in fullygrown beef animals the differences brought about by winter feed (hay, silage and cereals) and summer feed (grass and cereals) were small.

In feeding studies using urea as the sole or partial source of nitrogen (VIRTANEN 1967) protein production was based on actively-functioning rumen bacteria. Thus it was probable that the microbial population of the faeces would be different from that in cows given ordinary feed. For this reason the test cows' faeces were analysed, using a variety of culture media, for total count of bacterial colonies grown under aerobic and anaerobic conditions, and for total counts of live enterococci, coliform bacteria, microaerophilic lactobacilli, propionic acid bacteria, micrococci and lactate-utilising butyric acid bacteria.

\section{Materials and methods}

The composition of the test cows' feed in which urea was the only source of nitrogen is shown in Table 1 . The names 0 -cows and 0 -feed have been used for these cows and their feed. For those test cows with urea as a partial source of feed nitrogen the term surea-rich, low-protein" - abbreviated to ULP-cows has been used; the feed is denoted ULP-feed. Details of the ULP-feed are given in Table 2. Both types of feed were maintained basically unchanged the whole time, the size of the daily ration varying with rate of milk production. With the exception of a 1-2 hour period of excercise daily the cows were kept in the cowshed continually.

Table 1. Composition of the pellets used in the feeding of 0 -cows.

\begin{tabular}{|c|c|}
\hline $\boldsymbol{a}$-Cellulose ............... & $8.2 \%$ \\
\hline Potato starch ........... & $44.3 \%$ \\
\hline Crystalline sucrose ............ & $19.4 \%$ \\
\hline Mineral mixture $\left.{ }^{1}\right)$................... & $7.8 \%$ \\
\hline Urea and ammonium salts & \\
\hline (94: 6 calculated as & \\
\hline 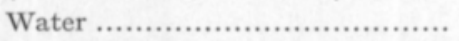 & 15.0 \\
\hline
\end{tabular}

1) Composition, g/100 g dry material:

Na $5.7 ; \mathrm{K} 10.4 ; \mathrm{Ca} 19.7 ; \mathrm{Mg} \mathrm{4.4;} \mathrm{Cl}$ 9.1; S 3.8; P 12.7;

Fe 0.197; Zn 0.071; Mn 0.040; Cu 0.013; Se 0.002; B 0.003;

Co 0.0004 ; I 0.001 ; Mo 0.0006 ; $\mathrm{Cr} 0.0006$.

Faeces samples were taken from the test cows once a week during the period January-November. The samples were taken about $\mathbf{1}$ hour after the start of feeding and brought to the laboratory for analysis within 3 hours. Pending dilution the storage was in sterile glass jars at $15-18^{\circ} \mathrm{C}$. According 
Table 2. Feed of the ULP-cows.

\begin{tabular}{|c|c|c|c|}
\hline \multirow{3}{*}{ Feed component } & \multicolumn{3}{|c|}{$\%$ of total feed units } \\
\hline & cow & cow & cow \\
\hline & Euru & Ula & Velo \\
\hline Sugar beet pulp .................... & 56.8 & 26.8 & 13.9 \\
\hline 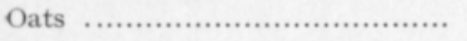 & 21.5 & 2.9 & 36.5 \\
\hline Potatoes ............................... & 0 & 33.3 & 12.9 \\
\hline Hay ..................................... & 0 & 0 & 16.9 \\
\hline 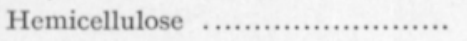 & 13.7 & 6.2 & 0 \\
\hline 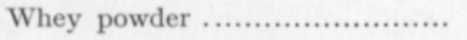 & 0 & 0 & 4.1 \\
\hline 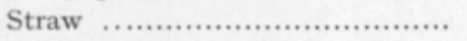 & 6.0 & 5.4 & 2.4 \\
\hline 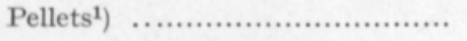 & 0 & 22.9 & 12.3 \\
\hline Soybean -plus maize oil ............. & 2.0 & 2.5 & 1.0 \\
\hline Urea- $\mathrm{N} \%$ of total nitrogen ....... & 56.0 & 60.0 & 41.0 \\
\hline Urea g/day ............................ & $360-240$ & $340-220$ & $240-125$ \\
\hline
\end{tabular}

1) Same as those given to 0 -cows.

to Crowther (1971) there are no large changes in the bacterial counts of human faeces during transport at $15^{\circ}$, provided the period is less than 24 hours.

Ringer's solution was used for the dilutions. All bacterial groups were inoculated from the same series of dilutions. The media and methods were as follows.

Aerobic and anaerobic bacteria: according to FLOCH et al. (1968). Anaerobic cultures: Gaspak system, $37^{\circ} 4$ days (ColleE et al. 1972). Coliform bacteria: aerobically, Mac Conkey's (Difco) agar, $37^{\circ} 1$ day.

Enterococci: aerobically, TITG agar (BARnes 1956) or Enterococcus medium (Slanetz and Bartley 1957), $37^{\circ} 2$ days.

Micrococci: Difco mannitol-salt agar, $37^{\circ} 1 \frac{1}{2}$ days.

Lactobacilli: Difco MRS Lactobacillus agar, $1.5 \%$, according to DE MAN et al. (1960) or using FLOCH et al. 's (1968) agar, microaerophilically, candle jar, $37^{\circ} 3$ days.

Lactate-utilising butyric acid bacteria: modified BERGERE et al.'s (1969) nutrient medium, MPN procedure.

Propionic acid bacteria: KAMBAR lactate agar under aqueous agar $30^{\circ} 7$ days (KAMBAR et al. 1952).

Gram- and spore staining was performed as described by NorRIs and SWAIN (1971).

In examining the results it must be remembered that the predominant part (more than $97 \%$ ) of the faecal microorganisms are anaerobic organisms, some being obligate anaerobes (Moore and Holdeman 1972). In culture procedures only a fraction of the microorganisms form colonies. According to the studies of MAKI and PICARD (1965) only 1-10\% of the microscopicallycounted bacteria are revealed in culture. The microscope does not distinguish live bacteria - one reason why its counts are higher. While some bacteria can pass undisrupted through the digestive tract, thereby taking stain in the normal manner, they are no longer capable of multiplying. 


\section{Results}

Counts of lactobacilli, micrococci, propionic acid bacteria and lactateutilising butyric acid bacteria in the faeces of 30 -cows and 3 ULP-cows were performed weekly for 41 weeks, using different culture media, and counts of aerobic and anaerobic bacteria, enterococci and coliform bacteria were made during 26 weeks.

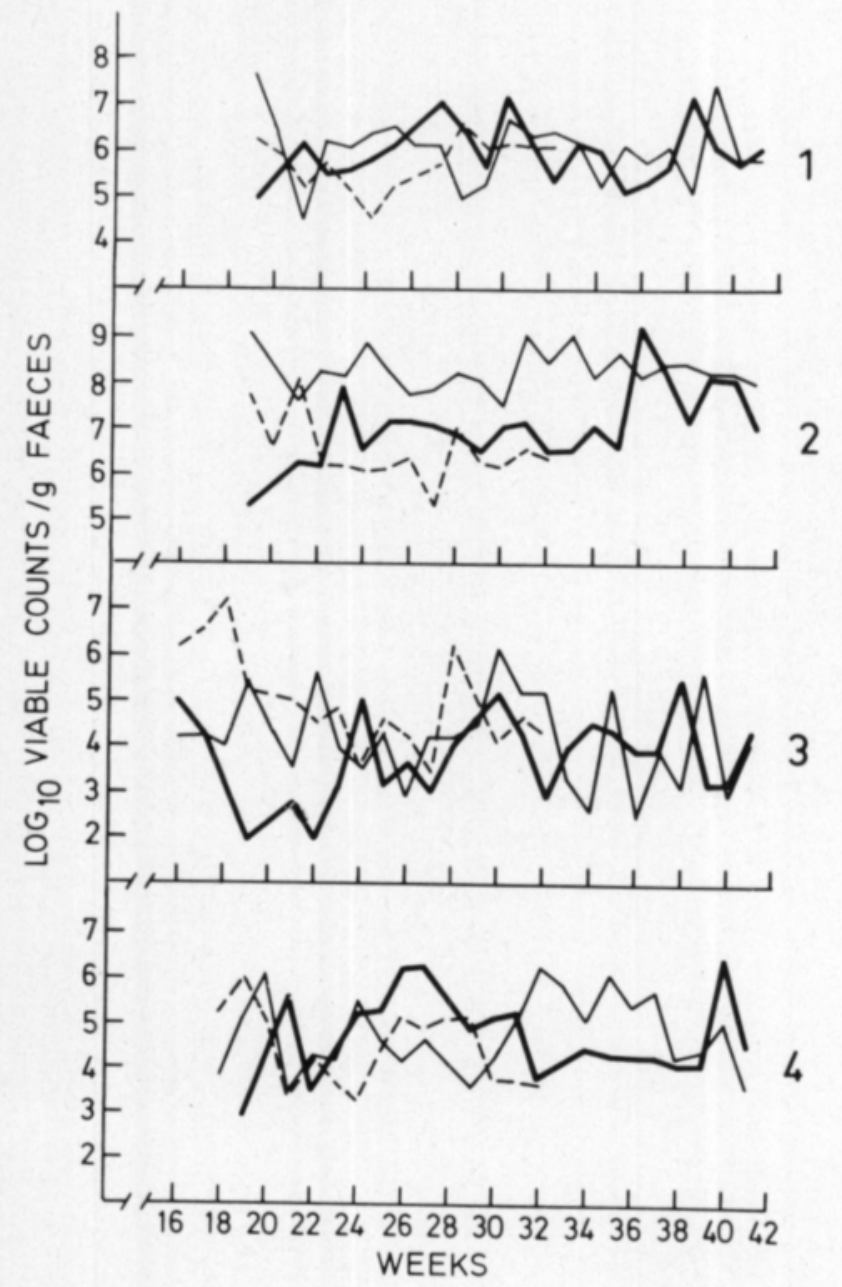

Figure 1. Colony counts of aerobes (1), anaerobes (2), enterococci (3) and coliform bacteria (4) in 0-cows' faeces: Oona - , Voona - , Tila --

The week-to-week variation in the number of bacterial colonies for each cow was very large (Figures $1-4$ ), such variation being evident in all bacterial groups. When the lactobacilli were numerous so too were the propionic acid bacteria and the enterococci. The total count of aerobically-cultured bacteria followed the same fluctuations. The group with the clearest deviation from this sequence of changes was the total anaerobically-cultured bacteria. The between-cow differences in bacterial counts of samples taken on the same day were considerable. 
Figure 2. Colony counts of lactobacilli (1), propionibacteria (2) and micrococci (3) in 0-cows' faeces: Oona Voona - Tila --
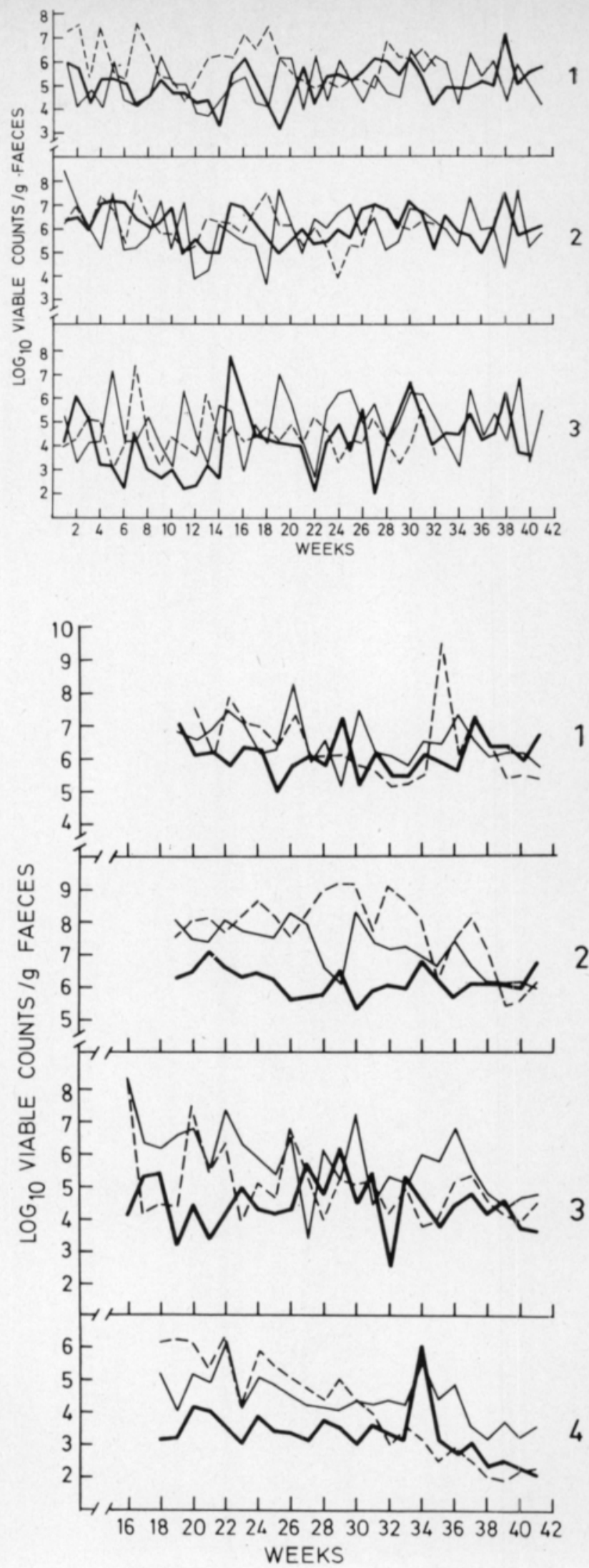

Figure 3. Colony counts of aerobes (1), anaerobes (2), enterococci (3) and coliform bacteria (4) in ULP-cows' faeces: Euru -, Ula Velo - - 


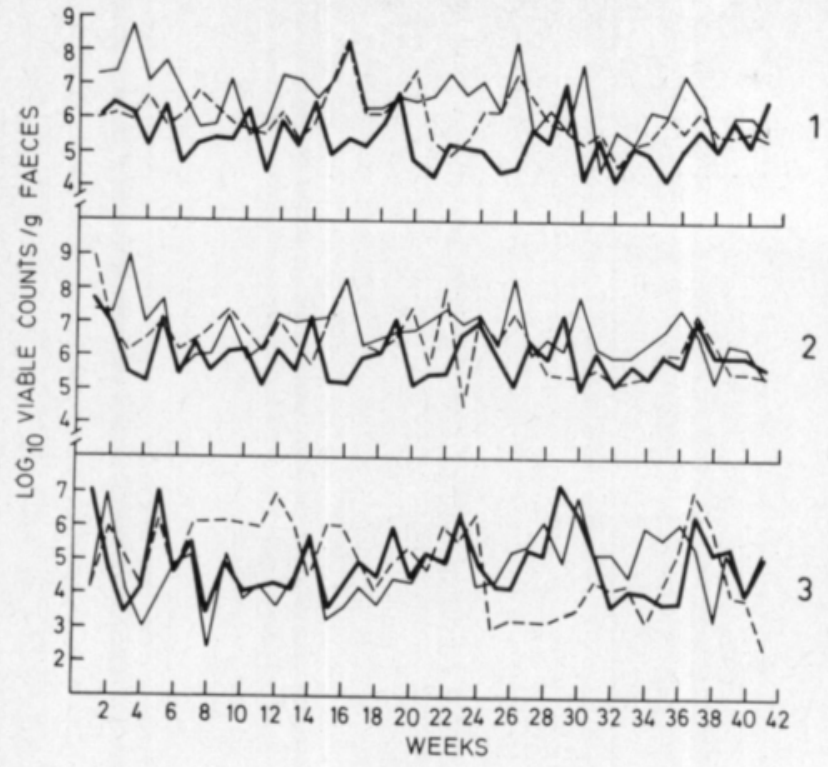

Figure 4. Colony counts of lactobacilli (1), propionibacteria (2) and micrococci (3) in ULP-cows' faeces: Euru Ula - Velo -

Table 3. Mean counts of live bacteria.

\begin{tabular}{|c|c|c|c|c|c|}
\hline \multirow{2}{*}{ Organism } & \multicolumn{3}{|c|}{0 -cows } & ULP-cows & \multirow[b]{2}{*}{$\mathbf{P}$} \\
\hline & $\mathbf{n}$ & $\log _{10}$ (counts/g) & $\mathrm{n}$ & $\log _{10}$ (counts/g) & \\
\hline Aerobes....................... & 59 & $6.1 \pm 0.7$ & 68 & $6.5 \pm 0.8$ & 0.01 \\
\hline Anaerobes ......................... & 59 & $7.6 \pm 1.0$ & 68 & $7.1 \pm 1.0$ & 0.05 \\
\hline Enterococci ...................... & 67 & $4.4 \pm 1.1$ & 77 & $5.3 \pm 1.1$ & 0.001 \\
\hline Coliform bacteria ................ & 61 & $4.8 \pm 0.8$ & 71 & $4.1 \pm 1.1$ & 0.001 \\
\hline Lactobacilli ...................... & 112 & $5.5 \pm 0.9$ & 120 & $6.1 \pm 0.9$ & 0.001 \\
\hline Propionibacteria ................. & 112 & $6.2 \pm 0.9$ & 120 & $6.5 \pm 0.9$ & 0.01 \\
\hline 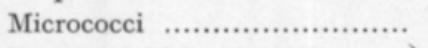 & 112 & $4.6 \pm 1.2$ & 120 & $4.9 \pm 1.1$ & 0.05 \\
\hline $\left.\begin{array}{l}\text { Lactate-utilising butyric } \\
\text { acid bacteria } \ldots \ldots \ldots \ldots \ldots \ldots . . . . . .\end{array}\right\}$ & 112 & $0.7 \pm 1.1$ & 120 & $1.6 \pm 1.0$ & 0.001 \\
\hline
\end{tabular}

Table 4. Proportion ( $\%$ ) of gram-positive bacteria in total stainable faecal bacteria from 0and ULP-cows.

Mean Range

0-cows:

Oona

17.7

$4.7-36.0$

Voona

21.6

$7.4-30.8$

ULP-cows:

$\begin{array}{lrr}\text { Euru } \ldots \ldots \ldots \ldots \ldots \ldots \ldots & 9.4 & 5.0-15.6 \\ \text { Ula } \ldots \ldots \ldots \ldots \ldots \ldots \ldots & 24.0 & 10.7-32.3 \\ \text { Velo } \ldots \ldots \ldots \ldots \ldots \ldots \ldots & 12.7 & 4.9-28.6\end{array}$


Each cow's average count of bacterial colonies $\left(\log _{10} / g\right.$ fresh faeces) is shown in Table 3. Usually the count of anaerobic bacteria was greater than that of aerobically-cultured bacteria. In the 0 -cows the difference between the counts of anaerobes and aerobes was greater than in the ULP-cows. Of the bacterial groups cultured on different media the so-called propionic acid bacterial group was the most numerous. The lactobacilli showed higher counts than the enterococci, and in the 0 -cows the numbers of coliform and micrococci too were larger than those of the enterococci. As regards the single cow counts, the average for ULP-cow Euru was lower than those of the other ULP-cows. Lactate-utilising butyric acid bacteria were found occasionally in all cows, their numbers being very small; their frequency of occurrence and count in the ULP-cows were greater than in the 0 -cows. At calving butyric acid bacteria were always present, even in exceptionally high numbers (4 600/g).

The ratio between the counts of gram-positive and gram-negative bacteria was determined on some of the samples, and it was found that the faeces of all cows contained more gram-negative bacteria than gram-positive. There was no appreciable difference between 0 -cows and ULP-cows in these counts (Table 4). The lowest counts of gram-positive bacteria were found in Euru's faeces. The mean proportion of bacterial spores in the total staining bacteria in ULP-cows' faeces was $26.7 \%$, in 0-cows' $6.5 \%$. The highest spore counts were found in Euru's faeces.

\section{Discussion}

In each animal there were large between-sample differences in numbers of bacterial colonies despite feed uniformity in quality and quantity. Examination of the mean counts shows that 0 -cow faeces contained more anaerobic bacteria than ULP-cow faeces $(\mathrm{P}<0.05)$ and fewer aerobic bacteria than ULP-cow faeces $(\mathrm{P}<0.01)$. MäKINEN $(1972)$ reported that the total count of rumen bacteria in 0 -cows was $2.23 \pm 0.36 \times 10^{10}$ and in ULP-cows $1.54 \pm$ $0.29 \times 10^{10}$. The number of colonies of microaerophilic lactobacilli in ULPcows' faeces was greater than in 0 -cows' $(\mathrm{P}<0.001)$. In both groups of test cows these counts were higher than those found by SмrтH (1961), who noted in fact than some cows had no faecal lactobacilli at all. They were present in every sample of 0 - and ULP-cow faeces, the counts ranging from $10^{4}$ to $10^{8} / \mathrm{g}$. Similarly, contents of coli bacteria too in faeces from both groups of test cows appear to be higher than in those cows studied by Sмгтн (1961). The presence of micrococci in beef animals' faeces was reported by WiLssens and Buttiaux (1958); the average count in ULP-cow's faeces was greater than in 0-cow's $(\mathrm{P}<0.05)$.

As regards total numbers, the faecal streptococci, one of the classes of enterococci, are regarded as the most important faecal microorganisms, just as they are in rumen fluid. However, the counts of enterococci were less than those of lactobacilli, particularly in 0-cows and very frequently in ULP-cows. Moreover, the numbers of both coli bacteria and micrococci too were greater than those of the enterococci. Even so the counts of enterococci colonies obtained here are similar to those recorded in the literature. Average counts 
are $10^{5}$ enterococci/g fresh cow faeces (MEDREK and BARnes 1962) and about $10^{6}$ streptococci/g (Smith 1961). Counts in 0 -cow faeces were $10^{4}-10^{5}$ and in ULP-cow faeces $10^{5}-10^{7} / \mathrm{g}$ fresh material. MEDREK and Barnes (1962) found that counts of enterococci during the winter did not differ greatly from those during the summer, the feeds containing hay, silage and cereals, and grass and cereals respectively.

Using KAMBAR lactate medium, the one generally employed for culturing propionic acid bacteria, the number of colonies from both groups of test cows was greater than those found with the other media used, with the exception of the anaerobic bacteria. The variations in the counts of these bacteria parallelled those of the lactobacilli and aerobic bacteria. According to MäkINEN (1972) rumen propionic acid contents of 0 -cows in particular were higher than in cows on ordinary feed.

Lactate-utilising butyric acid bacteria were present occasionally in all test cows' faeces, in small numbers usually. Whenever the counts were high there were signs of disturbed function in the cows' rumen. The presence of butyric acid bacteria in faeces is regarded generally as resulting from the fodder consumed. Wilssens and Buttiaux (1958) reported the occurrence of Clostridium butyricum during the winter in cow's faeces, which they attributed to the feeding of silage. It has been observed (KIURU et al. 1975, ALI-YRKKö and Antila 1975) that counts of butyric acid bacteria are low provided the cows' feed is of high quality, even though it may contain silage. However, the studies of ALI-YRKKö and ANTILA did reveal cows with faecal butyric acid bacteria despite the good quality of their feed and despite the absence of these bacteria from the other animals. Such was the case with those test cows used in the present study. Butyric acid bacteria were found even in 0cows, which were given feed of the highest possible purity. Faecal counts of these bacteria were elevated in both groups of cows during the time of calving. By means of the spore stain it was found that the content of spores as a proportion of the other stainable microorganisms was $6.5 \%$ in 0 -cows' faeces and $26.7 \%$ in ULP-cows'.

MÄKINEN (1972) gave the proportion of gram-positive bacteria as $35.9 \pm$ $0.4 \%$ of the total rumen bacteria of 0 -cows, $16.7 \pm 3.9 \%$ in ULP-cows and $10.7 \pm 2.1 \%$ in normally-fed cows. In faeces too with both 0 - and ULPcows the proportion of gram-negative bacteria was larger than that of the grampositive. MAKI and PICARD (1965) isolated intestinal bacteria from beef animals and found that most of them, with the exception of $E$. coli, were gram-positive; those bacteria which they were unable to identify were mainly gram-positive rods. The major portion of the microorganisms of the caecum consists of gram-negative rods and cocci (Orskov et al. 1970).

In the test cows the number of bacterial colonies in all the groups of bacteria studied was higher than those generally reported in the literature. According to Hungate et al. (1952) feed with a higher-than-normal content of carbohydrate alters the microbial flora of the rumen, and Orskov et al. (1970) state that addition of starch to feed increases bacterial numbers in the caecum.

The week-to-week fluctuations in the number of bacterial colonies in all the groups of bacteria were abrupt and of considerable size. In many cases the 
reason for the change could not be ascertained. Alterations in the amount of feed, which Sмгтн (1961) found to result in changes in the microbial population of the faeces, appeared in the present study to have had no effect. However there were a number of factors which naturally affected the counts of live bacteria in the faeces. A decline in the quality of the drinking water supplied to the 0-cows brought about ruminal disturbances and so the numbers of live lactobacilli, micrococci and propionic-acid bacteria in the faeces also declined. In addition, certain experimental operations, such as the sampling of rumen fluid and the lengthy (5-7 days) quantitative collection of urine and faeces, reduced the number of micro-organisms in the latter, probably a consequence of some functional abnormality in the rumen. On the other hand, the large weekly variations could have resulted in part from some stage in the work of taking and diluting the samples. Only one series of dilutions, from which all the cultures were inoculated, was made from each faeces sample. Parallel changes in several of the groups of bacteria from a single cow suggest that the factor in question was associated with the dilution. It is true that the anaerobic bacteria did not show this parallelism even though they were inoculated from the same series of dilutions as were the other bacterial cultures. In faeces from different cows the fluctuations occurred at different times, so that the factor in question could hardly have arisen from some part of the working procedure common to all the samples taken at the same time.

\section{REFERENCES}

AlI-YRKKö, S. \& ANTILA, M. 1975. Beobachtungen über den Clostridiengehalt der finnischen Silage und des Kuhmistes. Milchwissenschaft 30: 753-759.

BARnes, E. M. 1956. Methods for the isolation of faecal streptococci (Lancefield Group D) from bacon factories. J. Appl. Bacteriol. 19: 193-203.

Bergére, J.-L., Rousseaux, P., Ducruet, P., Mocouot, G., Hermier, J., Gouet, P. \& Zelter, S. Z. 1969. Expèrimentation sur la fabrication d'Emmental et de Comté avec du lait de vaches nourries a'l'ensilage A.I.V. Bulletin Technique d' information $\mathrm{n}^{\circ} 239$.

Collee, J. G., Watt, P., Fowler, E. B. \& Brown, R. 1972. An evaluation of the Gaspak system in the culture of anaerobic bacteria. J. Appl. Bacteriol. 35: 71-82.

Crowther, J. S. 1971. Transport and storage of faeces for bacteriological examination. J. Appl. Bacteriol. 34: 477-483.

De Man, J. C., Rogosa, M. \& Sharpe, M. E. 1960. A medium for the cultivation of lactobacilli. J. Appl. Bacteriol. 23: 130-135.

Floch, M. H., Gerschengoren, W. \& Freedman, L. R. 1968. Methods for the quantitative study of the aerobic and anaerobic intestinal bacterial flora of man. Yale J. Biol. Med. 41: $50-61$.

Hungate, R. E., Dougherty, R. W., Bryant, M. P. \& Cello, R. M. 1952. Microbiological and physiological changes associated with acute indigestion in sheep. Cornell Vet. 42: $423-449$.

Kambar, C. S., Reinbold, G. W. \& Hussong, R. V. 1952. A plating method for the isolation and enumeration of propionibacteria. J. Dairy Sci. 35: 915-919.

Kruru, V., Moisio, T. \& KreUla, M. 1975. On the fermentation processes of various silages and the influence of their feedıng on the clostridia content of cow's faeces. Karjantuote 58: $4-8$.

MAKI, L. \& Picard, K. 1965. Normal intestinal flora of cattle fed high-roughage rations. J. Bacteriol. 89: 1214-1249.

MedreK, T. F. \& BARnes, E. M. 1962. The distribution of group D streptococci in cattle and sheep. J. Appl. Bacteriol. 25: 159-168. 
Moore, W. E. C. \& Holdeman, L. V. 1972. Identification of anaerobic bacteria. Am. J. Clin. Nutr. 25: 1306-1313.

MÄKınen, S. 1972. Aspects of the nitrogen metabolism and nutritional status of urea fed dairy cattle. Ann. Acad. Sci. Fenn. A. II. Chem. 165: 1.

Norris, J. R. \& Swain, H. 1971. Staining bacteria. Methods in microbiology 5 A: 105-134. London.

Orskov, E. R., Fraser, C., Mason, V. C. \& Mann, S. O. 1970. Influence of starch digestion in the large intestine of sheep on cecal fermentation, cecal microflora and faecal nitrogen. Br. J. Nutr. 24: 671-682.

Slanetz, L. W. \& Bartley, C. H. 1957. Numbers of entrococci in water, sewage, and feces determined by the membrane filter technique with an improved medium. J. Bacteriol. 74: $591-595$.

Sмrтн, H. W. 1961. The development of the bacterial flora of the faeces of animals and man: the changes that occur during ageing. J. Appl. Bacteriol. 24: 235-241.

Wilssens, A. \& Butriaux, R. 1958. Les bactéries de la flore fecale de la vache saine. Ann. Inst. Pasteur 94: 332-340.

Virtanen, A. I. 1967. Milk production on a protein-free and protein-poor feed. Neth. Milk Dairy J. 21: 223-244.

Ms received October 10, 1979.

\title{
SELOSTUS
}

\section{Lypsylehmien sonnan mikrobeista urean ollessa ruokinnan ainoana tai osittaisena typenlähteenä}

\author{
T. Ettala, A. Seuranen ja M. Kreula \\ Biokemiallinen Tutkimuslaitos, Kalevankatu 56 B, 00180 Helsinki 18
}

Puhdistetuilla proteiinittomilla rehuilla ruokittujen lypsylehmien, joilla urea on ollut ainoana typenlähteenä (0-lehmät) ja vähän proteiinia, runsaasti ureaa sisältävillä rehuilla ruokittujen lehmien (ULP-lehmät) sonnasta on määritetty elävien bakteerien määrät kasvattamalla mikrobeja erilaisilla kasvualustoilla. Sontanäytteitä on otettu kolmelta 0-lehmältä ja kolmelta ULPlehmältä kerran viikossa. Näytteistä on laskettu 41 viikon ajan laktobasillien. mikrokkien, propionihappobakteerien ja laktaattia käyttävien voihappobasillien määrät ja 26 viikon ajan anaerobisesti ja aerobisesti kasvaneet pesäkkeet, enterokokkien sekä koliryhmän bakteerien pesäkkeet grammassa tuoretta sontaa.

Anaerobisia bakteereita on 0-lehmillä ollut $10^{5}-10^{9}$ ja ULP- lehmillä $10^{6}-10^{9}$ pesäkettä, aerobisia vastaavasti $10^{5}-10^{7}$ ja $10^{5}-10^{8}$ pesäkettä/g sontaa.

•Propionihappobakteereita» on sekä 0 - että ULP-lehmillä ollut $10^{4}-10^{7}$ pesäkettä, laktobasilleja 0-lehmillä $10^{3}-10^{8}$ ja ULP-lehmillä $10^{4}-10^{8}$ pesäkettä sekä mikrokokkeja molemmilla ruokintaryhmillä $10^{2}-10^{7}$ pesäkettä/g sontaa. Enterokokkeja on 0-lehmillä ollut $10^{2}-10^{6}$ ja ULP-lehmillä $10^{3}-10^{7}$ pesäkettä sekä koliryhmän bakteereita vastaavasti $10^{3}-10^{6}$ ja $10^{2}-$ $10^{6}$ pesäkettä/g sontaa. Laktaatteja käyttäviä voihappobasilleja on ollut $0-4600 \mathrm{kpl}$ grammassa tuoretta sontaa ja ne ovat 0-lehmillä olleet harvinaisempia kuin ULP-lehmillä. Kaikkien bakteerien määrissä on viikosta toiseen esiintynyt suuria vaihteluita. Samalla lehmällä on yhtäaikaa ollut lähes kaikkia tutkittuja bakteereita vähän ja seuraavalla viikolla niitä kaikkia on taas voinut olla runsaasti. Eri yksilöillä vaihtelurytmi on ollut erilainen. Eniten kunkin yksilön vaihtelurytmistä ovat poikenneet anaerobisesti kasvatetut bakteerit.

Näytteistä on määritetty myös gram-negatiivisten ja gram-positiivisten bakteerien suhde ja todettu, että kummallakin ruokintaryhmällä on gram-negatiivisten bakteerien määrä ollut gram-positiivisia suurempi. Bakteeri-itiöitten esiintymistä on niinikään tutkittu ja todettu, että niiden osuus kaikista värjääntyvistä bakteereista on ollut keskimäärin $6,5 \%$-lehmillä ja $26,7 \%$ ULP-lehmillä. 